\title{
Assessment of the Depth of the Deformed Layer in the Roller Burnishing Process
}

\author{
M. Kowalik, ${ }^{a}$ T. Mazur, ${ }^{a}$ and T. Trzepiecinski ${ }^{\mathrm{b}, 1}$ \\ a Pulaski University of Technologies and Humanities, Institute of Mechanical Engineering, Radom, \\ Poland \\ ${ }^{\mathrm{b}}$ Rzeszow University of Technology, Faculty of Mechanical Engineering and Aeronautics, Rzeszow, \\ Poland \\ ${ }^{1}$ tomtrz@prz.edu.pl
}

УДК 539.4

\section{Визначення глибини деформованого шару при обкочуванні роликом}

\author{
М. Ковалік ${ }^{a}$, Т. Мазур ${ }^{a}$, T. Тржепічінські ${ }^{0}$ \\ ${ }^{\text {a } Т е х н о л о г о-г у м а н і т а р н и и ̆ ~ у н і в е р с и т е т ~ і м . ~ К а з и м и р а ~ П у л а в с ь к о г о ~ в ~ Р а д о м і, ~ І н с т и т у т ~ м а ш и н о-~}$ \\ будування, Радом, Польща \\ ${ }^{\sigma}$ Технологічний університет Жешува, Факультет машинобудування та аеронавтики, Жешув, \\ Польща
}

Наведено методики визначення глибини пластично деформованого верхнього шару матеріалу при обкочуванні роликом. Аналітичний метод розроблено на основі теорії Гериа-Беляєва. Глибину такого шару отримано як функцію зусилля обкочування, міциності матеріалу $i$ геометрії ролика. Аналітичний розв'язок перевірено оригінальним методом, щуо базується на вимірюванні лицьового профілю кілець. Розроблено математичну модель теоретичного розв'язку і план експериментів. Чисельне моделювання глибини пластично деформованого шару виконано методом скінченних елементів. Результати, отримані аналітичним $і$ експериментальним методами, показують їх хорому відповідність.

Ключові слова: глибина деформованого шару, пластична деформація, скінченноелементний метод, обкочування роликом.

Introduction. Many material forming technologies such as burnishing, thread rolling, spline rolling, knurling, and drawing lead to both the deformation of the surface layer of the material and changes in its properties. This phenomenon introduces compressive stresses into the surface layer increasing its surface hardness, and both static and fatigue strength $[1$, 2]. Under the pressure of the rounded tool, deformation not only occurs in the plastic forming processes, but also in turning, milling, grinding [3] or even laser surface treatment [4]. The deformation of the surface layer occurs during deep drawing of the thin sheet metal, where the complex stress state caused by the rounded tools leads to the change in friction conditions and loss of stability of the sheet material undergoing plastic tension [5, 6]. The scale of plastic deformation in the above processes is smaller than in roller burnishing, but it is always possible to observe a plastically deformable surface layer. Plastic deformations of the metal surface can occur under relatively small forces, i.e. during measurements or assembly [7-9]. Roller burnishing causes strain hardening of the material and introduces compressive stresses into the surface layer that increase the hardness [10] and strength of the surface layer of the material [11]. In order to obtain greater depths of the 
deformed surface layer, very high burnishing forces are required, which result in the pitting phenomenon occurring during the burnishing process or exploitation $[12,13]$. The fatigue life of machine parts depends on the thickness of the plastically deformed surface layer $\delta$. The depth of the deformation-reinforced surface layer $\delta$ in the case of machine parts that operate under fatigue conditions becomes the basic parameter determining the conditions of burnishing $[14,15]$. The aim of reinforcement burnishing is to achieve the maximum possible depth of plastic deformation of the surface layer [16, 17] which will not cause microcracks of the surface $[18,19]$.

Figure 1a shows a shaft with a diameter of $d$ before burnishing (grey area). The parameter which characterizes the shaft material is yield stress $R_{e}$ (grey area in Fig. 1). The red line represents the stress caused by external loads. The shaft after roller burnishing with the strain hardening caused by cold work at a depth of $\delta$ in the surface layer exhibits greater yield strength with a value of $\Delta R_{e}$ (Fig. 1b.) If the depth of the deformation layer is too small, the stress line (inclined solid line in Fig. 1) caused by the external load will be outside the permissible stress line (grey area in Fig. 1c), and a crack will be formed under the strain hardened layer.

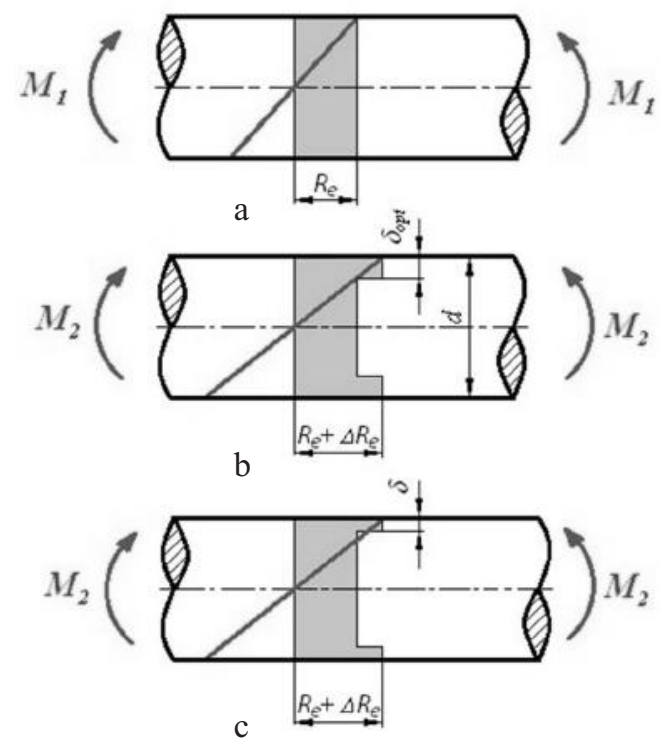

Fig. 1. Distribution of shaft strength (grey area): (a) before burnishing; (b) after burnishing; (c) load case of shaft with cracks in the subsurface layer.

The depth of the reinforced layer should be $\delta_{\text {opt }}$ to ensure complete utilization of the fatigue strength increment. In the experimental investigations, it was found that to a certain value of $\delta / d$ the fatigue strength increases with an increase of the depth of deformation $\delta$. The permissible value of ratio $\delta / d \geq 0.05$ has been determined by Malag et al. [20].

In this article the problem of determining the parameters of the roller burnishing process is analyzed. The parameters analyzed are the yield stress $R_{e}$ of the ring material, the burnishing force $F$, the diameter of the burnishing roller $D$, and the radius of the burnishing roller $r$.

1. Analytical Determination of the Depth of the Plastically Deformed Surface Layer. The values of surface pressures affect both elastic and plastic deformation in the surface layer of the workpiece in the process of roller burnishing. Burnishing introduces compressive stresses into the top layer of material in order to increase its strength. The fatigue life of machine parts depends on the depth of the plastically deformed top layer $\delta$. 
The value of the depth of the deformation-induced layer $\delta$ in the case of machine parts operating at fatigue conditions becomes the basic determinant which influences the technological parameters of the processing. The simplifying assumption was made that the roller was not deformable, and the material adjacent to the roll exclusively underwent elastic strain irrespective of the force value $F$.

A general solution of the contact problem based on the theory of elasticity was developed by Hertz [21]. He explained the relationship of the pressure $p$ on the contact surface between two symmetrical bodies as a function of the compression force $F$. Stresses on the contact surface often exceed the value of yield stress and even the strength of the material.

The dotted curve $\sigma_{\text {red }}$ represents the distribution of the elastic tensions where the value $\sigma_{\text {red }}=R_{e}$ on the line marked $k-k$ (Fig. 2). The tensions $\sigma_{\text {red }}>R_{e}$, i.e., the plastic deformation area, appear in the area over the line $k-k$, while below there is the area of elastic strain [14]. In practice, two areas of different types of deformation are produced, but the division between them is not as sharp as presented in Fig. 2. Hence, the coordinate $z=\delta$ that determines the line $k-k$, where $\sigma_{\text {red }}=R_{e}$, divides the material into two zones: the upper plastic deformed one and lower elastic deformed one.

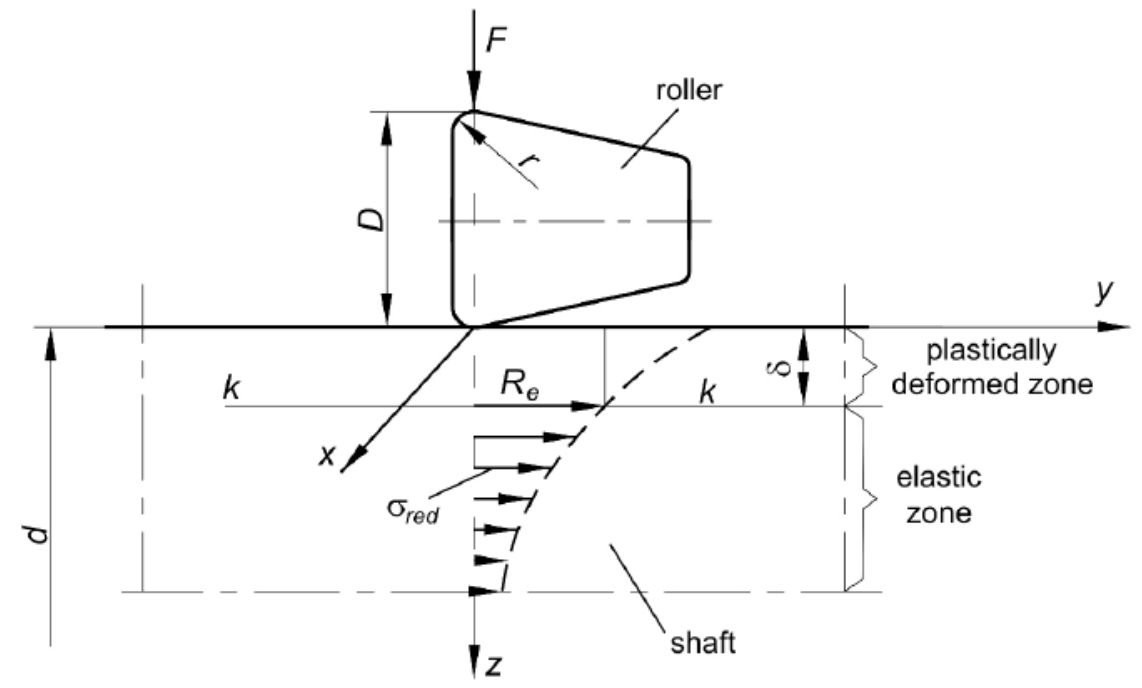

Fig. 2. The roller burnishing scheme used to calculate the thickness of the plastically deformed surface layer along the axis of action of the thrust force (at $x=y=0$ ).

The contact stress can be carried by material due to the fact that the stress state in the surface layer is similar to triaxial compression [20]. The calculations performed by Bielayev [22] indicate that the highest strain on the material is not located on the contact surface of the body, but at a slight depth below the surface layer. This location is well known as the Bielayev point. The principal stresses in the formula for the evaluation of the Huber-Mises-Hencky [23] equivalent stresses have been determined on the basis of the elastic stress components developed by Bielayev [22].

It could be assumed that the tensions in the upper area of plastic deformation do not transform substantially the distribution of the tensions in the lower zone. Thus, to calculate the coordinate $z=\delta$ that is the point of division between the two zones, strain theory can be applied to know the position of the line $k-k$. The analytical calculations were based on the Hertz-Bielayev method that describes the contact of two deformed bodies. The solution concerns the symmetric case where it is assumed that the contact surface is of ellipsoid shape with equal semi-axes. 
After a series of calculations and transformations [14], an analytical relationship (Eq. (1)) was obtained for the calculation of the thickness of the plastically deformed layer $\delta$ in the case of the general (unsymmetrical) stress state. Equation (1) can be used in calculations for typical roller burnishing using a roller with a torus profile:

$$
\begin{aligned}
& \frac{F}{R_{e} e^{2}}=\frac{\sqrt{2}}{3} \pi \frac{1-w}{\sqrt{w}}\left[\left[\frac{\delta}{e} \sqrt[4]{w}(1-v)\left[\frac{1+w}{w} E(\varphi, k)-2 F(\varphi, k)\right]+1-2 v+\right.\right. \\
& \left.+\frac{w(1+w)(1-2 v)-2\left(\frac{\delta}{e}\right)^{2} \sqrt{w}[v(1+w)-1]}{2 w \sqrt{\left(w+\left(\frac{\delta}{e}\right)^{2} \sqrt{w}\right)\left(1+\left(\frac{\delta}{e}\right)^{2} \sqrt{w}\right)}}\right]^{2}+\left[\frac{\delta}{e} \sqrt[4]{w}\left[\frac{v-w}{w} E(\varphi, k)+(1-v) F(\varphi, k)\right]+\right. \\
& \left.+\frac{1-2 v}{2}+\frac{w\left(1+\left(\frac{\delta}{e}\right)^{2} \sqrt{w}\right)-2 v\left(w+\left(\frac{\delta}{e}\right)^{2} \sqrt{w}\right)}{2 w \sqrt{\left(w+\left(\frac{\delta}{e}\right)^{2} \sqrt{w}\right)\left(1+\left(\frac{\delta}{e}\right)^{2} \sqrt{w}\right)}}\right]^{2}+\left[\frac{\delta}{e} \sqrt[4]{w}\left[\frac{1-w v}{w} E(\varphi, k)+(1-v) F(\varphi, k)\right]+\right. \\
& \left.+\frac{1-2 v}{2}+\frac{w^{2}(2 v-1)+\left(\frac{\delta}{e}\right)^{2} \sqrt{w}[2(w v-1)+w]}{2 w \sqrt{\left(w+\left(\frac{\delta}{e}\right)^{2} \sqrt{w}\right)\left(1+\left(\frac{\delta}{e}\right)^{2} \sqrt{w}\right)}}\right]^{2},
\end{aligned}
$$

and

$$
\begin{gathered}
E(\varphi, k)=\operatorname{arcctg}\left(\frac{\delta}{e} \sqrt[4]{w}\right)\left(1-\frac{1}{4}(1-w)-\frac{3}{64}(1-w)^{2}\right)+ \\
+\frac{\delta}{e} \sqrt[4]{w} \frac{1}{1+\left(\frac{\delta}{e}\right)^{2} \sqrt{w}}\left[\frac{1}{4}(1-w)+\frac{3}{64}(1-w)^{2}+\frac{1}{32}(1-w)^{2} \frac{1}{1+\left(\frac{\delta}{e}\right)^{2} \sqrt{w}}\right] \\
+\frac{\delta}{e} \sqrt[4]{w} \frac{1}{1+\left(\frac{\delta}{e}\right)^{2} \sqrt{w}}\left[\frac{1}{4}(1-w)+\frac{9}{64}(1-w)^{2}+\frac{3}{32}(1-w)^{2} \frac{1}{1+\left(\frac{\delta}{e}\right)^{2} \sqrt{w}}\right] \\
{\left[\begin{array}{l}
\frac{\delta}{w} \\
\left.\frac{4}{w}\right)\left(1+\frac{1}{4}(1-w)+\frac{9}{64}(1-w)^{2}\right)+
\end{array}\right.}
\end{gathered}
$$


where $F$ is the force applied, $R_{e}$ is the yield stress of the deformable body, $v$ is Poisson's ratio, $E$ is the Young modulus, $e$ is the equivalent semi-axis of the impression ellipse (Hertz semi-axis), $e=\sqrt{a b}, a$ and $b$ are the smaller and larger semi-axis of the impression ellipse, respectively, and $w=a^{2} b^{2}<1$ is a dimensionless auxiliary factor.

The coefficient $w$ depends solely on the geometry of the contacting surfaces $(D, d, r)$ according to the relation:

$$
w=\frac{E(k)}{2 r\left(\frac{1}{D}+\frac{1}{d}\right)(K(k)-E(k))+K(k)},
$$

where

$$
\begin{aligned}
& E(k)=\frac{\pi}{2}\left(1-\frac{1}{4}(1-w)-\frac{3}{64}(1-w)^{2}-\frac{5}{256}(1-w)^{3}-\frac{175}{16384}(1-w)^{4}\right), \\
& K(k)=\frac{\pi}{2}\left(1+\frac{1}{4}(1-w)+\frac{9}{64}(1-w)^{2}+\frac{25}{256}(1-w)^{3}+\frac{1225}{16384}(1-w)^{4}\right) .
\end{aligned}
$$

The equivalent semi-axis of the ellipse of the Hertz impression should be calculated according to the relation:

$$
e=\sqrt{\frac{3\left(1-v^{2}\right) F R}{E}},
$$

where $R$ is the equivalent curvature radius, $\frac{1}{R}=\frac{1}{r}+\frac{2}{D}+\frac{2}{d}$.

The graphical solution of Eq. (5) represents a group of curves in the dimensionless coordinates $F\left(R_{e} e^{2}\right)^{-1}=f\left(w, \delta e^{-1}\right)$, where each curve corresponds to a different value of $w$. For the case of the symmetrical stress state, when the semi-axes of impression $a$ and $b$ are equal, that is, $w=1$ we can obtain an analytical relation used in roller burnishing using a ball:

$$
\frac{F}{R_{e} e^{2}}=\frac{4 \pi}{3}\left[\frac{3}{1+\left(\frac{\delta}{e}\right)^{2}}+2(1+v)\left(\frac{\delta}{e} \operatorname{arcctg} \frac{\delta}{e}-1\right)\right]
$$

Due to the complexity of the general solution of Eq. (1), its practical use requires the application of numerical methods, nomograms or tabulated values. Therefore, a simplified, adequate mathematical model of this theoretical solution for industrial applications has been developed. The least squares method was used to calculate the regression coefficients:

$$
\delta_{t}=R^{-0.001} \frac{1.025 F^{0.5}-2.6}{1.4 R_{e}^{0.5} \exp \left(0.0001 R_{e}\right)-0.02} .
$$

The assessment of the adequacy rating of the regression model (Eq. (7)) was determined using Snedecor's $F$-distribution at a significance level of 0.05 . The set of data presented in Table 1 is used to determine the adequacy of the mathematical model. 
$\mathrm{T}$ a $\mathrm{b} 1$ e 1

\section{Data for the Calculation of the Theoretical Solution}

\begin{tabular}{|c|c||}
\hline Characteristic & Mathematical model (Eq. (7)) for theoretical solution \\
\hline Force applied $F, 10^{3} \mathrm{~N}$ & $1,2,3,4,5,6,7,8,9,10,11,12,13$ \\
\hline Yield stress $R_{e}, \mathrm{MPa}$ & $300,400,500,650,750,850,990,1100,1200$ \\
\hline $\begin{array}{c}\text { Equivalent curvature radius } \\
R, \mathrm{~mm}^{-1}\end{array}$ & $\begin{array}{c}1.3812(D=100 \mathrm{~mm}, r=1.5 \mathrm{~mm}, d=54 \mathrm{~mm}, w=0.06) \\
2.5737(D=110 \mathrm{~mm}, r=3.0 \mathrm{~mm}, d=54 \mathrm{~mm}, w=0.1276) \\
3.9182(D=110 \mathrm{~mm}, r=5.0 \mathrm{~mm}, d=54 \mathrm{~mm}, w=0.217) \\
5.2529(D=100 \mathrm{~mm}, r=7.5 \mathrm{~mm}, d=54 \mathrm{~mm}, w=0.3491)\end{array}$ \\
\hline $\begin{array}{c}\text { Number of test series } \\
\text { Number of repetitions } \\
\text { in series }\end{array}$ & $2\left(E=2.12 \cdot 10^{5} \mathrm{MPa}\right.$ and $\left.E=2.15 \cdot 10^{5} \mathrm{MPa}\right)$ \\
at constant $v=0.3$
\end{tabular}

2. Experimental Verification of the Depth of Plastic Deformation. Precise determination of the depth of the plastically deformed layer is difficult due to slight deformation at the boundary of the plastic and elastic zone, the lack of visible changes in the microstructure, and minimal changes in microhardness. Most studies determine the depth of the plastically deformed layer by measuring microhardness in the cross section of the sample $[24,25]$. Figure 3 shows the scheme of the original measurement method that consists in determining the thickness of the deformed layer using rings. The method involves profilographometric measurements of the disconnected rings (samples) which are flat-faced in the package on the mandrel. The ring material undergoes plastic deformation in the surface layer causing wrapping of the end face of the ring in the direction of movement of the rolling tool. A distinct deformation is observed on the end faces of the rings. This deformation does not cause any dislocation (the ring faces are in constant contact). Three measuring rings with an outer diameter of $d=54 \mathrm{~mm}$ and a thickness of $7 \mathrm{~mm}(2-4$ in Fig. 3) are fastened between two $15 \mathrm{~mm}$ thick discs (1 and 5 in Fig. 3) on a mandrel with a diameter of $30 \mathrm{~mm}$.

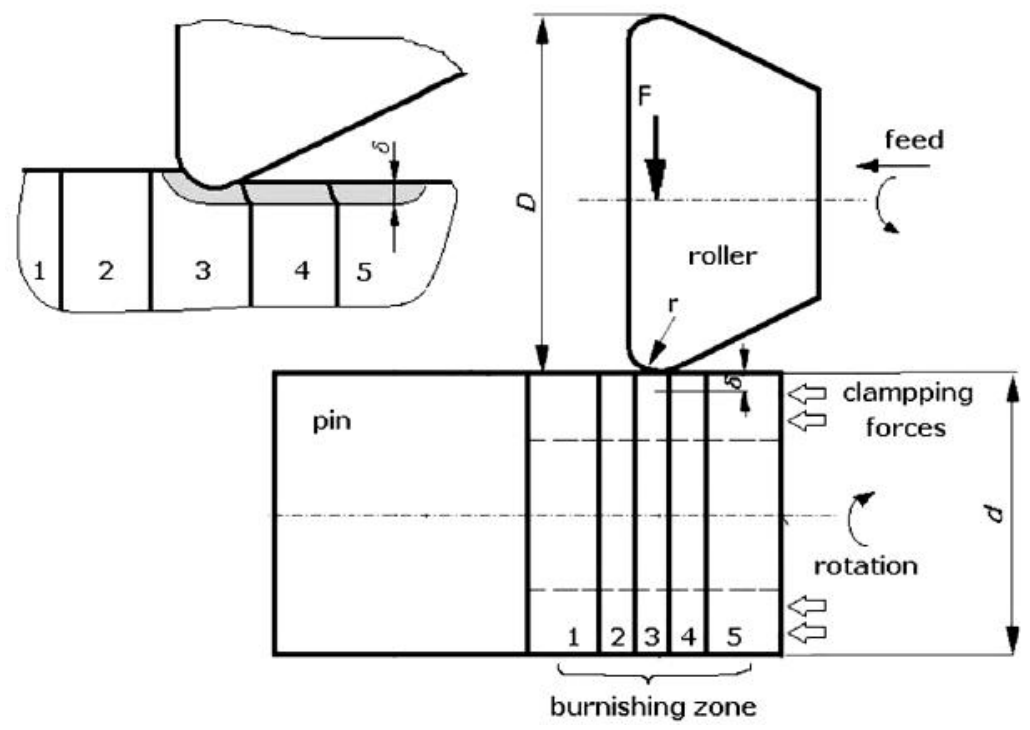

Fig. 3. Method for measuring the depth of plastic deformation of the surface layer using rings. 


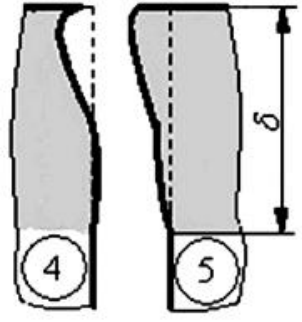

a

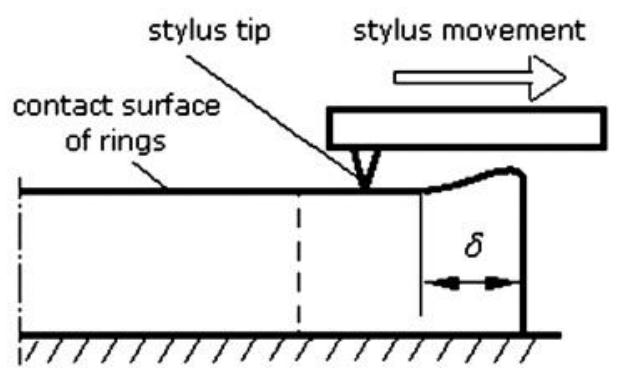

$\mathrm{b}$

Fig. 4. Deformation of adjacent ring side surfaces corresponding with the depth $\delta$ of plastic deformation (a) and measurement of the depth $\delta$ of plastic deformation of the burnished surface; 4 and 5 are numbers of contact rings.

After disassembling the package of rings, measurements were made on the end faces (Fig. 4a) of each ring along radial directions and the thickness of the deformed layer $\delta$ was determined using a stylus (Fig. 4b).

3. Numerical Modeling. A 3D parametric finite element (FE) model was built using the commercial FE-package MSC.Marc + Mentat. Simulation of the roller burnishing process of $41 \mathrm{Cr} 4$ steel rings was performed for the scheme shown in Fig. 3. The geometries of the tool and workpiece were modelled in accordance with the experimental setup. The mechanical properties of the ring material (Table 2) were determined in a uniaxial tensile test, and the hardness was determined by the Rockwell method. The remaining parameters assumed in calculations for $41 \mathrm{Cr} 4$ steel included: density $\rho=7800 \mathrm{~kg} / \mathrm{m}^{3}$, the Young modulus $E=2.15 \cdot 10^{5} \mathrm{MPa}$, and Poisson's ratio $v=0.33$.

$\mathrm{T}$ a b 1 e 2

Selected Mechanical Properties and Hardness of the Quenched and Tempered 41Cr4 Steel

\begin{tabular}{|c|c|c|c|}
\hline$R_{e}, \mathrm{MPa}$ & $R_{m}, \mathrm{MPa}$ & $A_{5}, \%$ & Hardness, HRC \\
\hline 990 & 1070 & 17 & 36 \\
\hline
\end{tabular}

The forming roll made of $145 \mathrm{Cr} 6$ steel following quenching and tempering was considered to be rigid, no deformation was assumed in this part during roller burnishing. The kinematics of the roller movement corresponded to real conditions. The load applied was $1000 \mathrm{~N}$. The numerical model of the roller burnishing is presented in Fig. 5. The roller is modelled by outer rigid surfaces in the vicinity of the working surface of the roller. The model of the pin and rings consisted of 8-node isoparametric brick elements. The numerical model of the rings and pin was meshed by 72,000 elements. To improve the accuracy of the computations, the outer layer of the shaft, in which the greatest strains appeared, was meshed more densely.

To describe the contact phenomena between the shaft and rollers, we have applied the arctan function model [26] of uniform friction dependent on metal-tool slip velocity, Eq. (8),

$$
\sigma_{t} \leq-\mu \frac{\sigma}{3} \frac{2}{\pi} \arctan \left(\frac{v_{r}}{v_{c}}\right) \frac{v_{r}}{\left|v_{r}\right|}
$$

where $\mu$ is the friction coefficient, $\sigma$ is the equivalent stress, $\mathrm{MPa}, v_{r}$ is the relative sliding velocity, and $v_{c}$ is the relative sliding velocity when sliding occurs. 


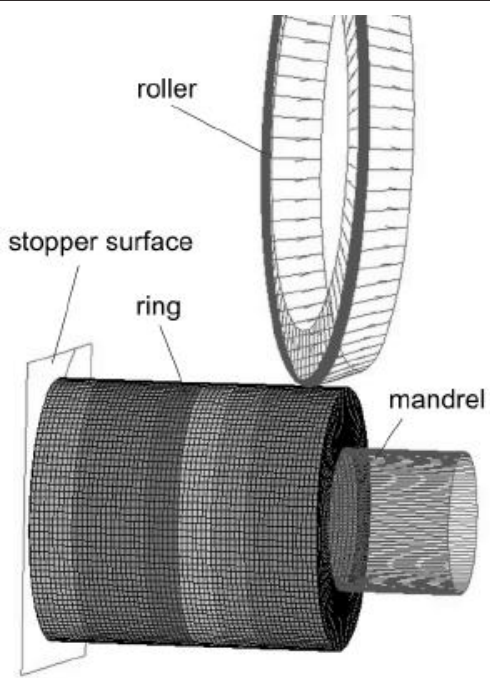

Fig. 5. Schematic illustration of the tool and workpiece for the FE model.

It is recommended in [26] that the value of $v_{c}$ be $1-10 \%$ of the relative sliding velocity $v_{r}$. For the present analyses we have assumed $v_{c}=0.08$ with a friction coefficient $\mu=0.1$ [27].

4. Results. A zone of plastic deformation (dark surface layer in Fig. 6) is visible on the faces of rings after deformation. On the basis of measurements of $\delta$ on rings made of $41 \mathrm{Cr} 4$ steel in a heat-treated state $\left(R_{e}=990 \mathrm{MPa}\right.$ and $\left.E=2.15 \cdot 10^{5} \mathrm{MPa}\right)$ and an annealed state $\left(R_{e}=400 \mathrm{MPa}\right.$ and $\left.E=2.12 \cdot 10^{5} \mathrm{MPa}\right)$, an appropriate mathematical model was developed in the form:

$$
\delta_{p}=R^{-0.006} \frac{0.99 F^{0.54}-3.6}{6.6 R_{e}^{0.28} \exp \left(0.0004 R_{e}\right)-6.8}
$$

The assessment of the adequacy of this model (Eq. (9)) was determined using Snedecor's $F$-distribution at a significance level of 0.05 . The evaluation was carried out for the data presented in Table 3.

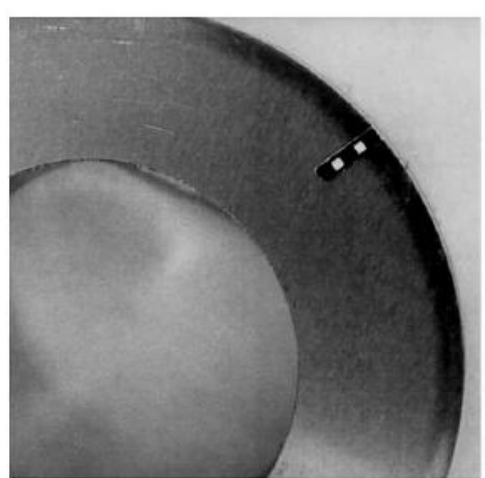

a

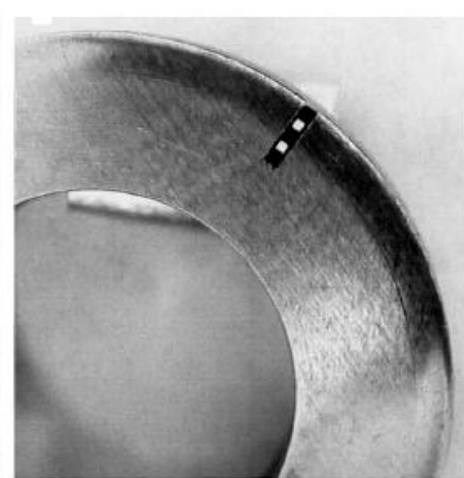

b

Fig. 6. Pictures of the faces of selected rings after deformation with the visible zone of plastic deformation (dark surface layer); forces applied: $F=300$ (a) and $900 \mathrm{daN}$ (b). 
T a b 1 e 3

\section{Data for Evaluation of the Mathematical Model from Experimental Data}

\begin{tabular}{||c|c||}
\hline Characteristic & Mathematical model (Eq. (9)) for experimental data \\
\hline Force applied $F, 10^{3} \mathrm{~N}$ & $3,5,7,9$ \\
\hline Yield stress $R_{e}, \mathrm{MPa}$ & 400,990 \\
\hline Equivalent curvature radius & $\begin{array}{c}1.3812(D=100 \mathrm{~mm}, r=1.5 \mathrm{~mm}, d=54 \mathrm{~mm}, w=0.06) \\
2.5737(D=110 \mathrm{~mm}, r=3.0 \mathrm{~mm}, d=54 \mathrm{~mm}, w=0.1276) \\
3.9182(D=110 \mathrm{~mm}, r=5.0 \mathrm{~mm}, d=54 \mathrm{~mm}, w=0.217)\end{array}$ \\
\hline Number of test series & $4 \cdot 2 \cdot 3=24$ \\
\hline Number of repetitions in series & $8 \cdot 6=48(8$ measuring surfaces, 6 measurements on each) \\
\hline
\end{tabular}

Examples of graphs of the relation $\delta=f(F)$ for $R=1.3812 \mathrm{~mm}^{-1}$ which were obtained on the basis of the theoretical solution (Eq. (1)) and the experimental measurements are shown in Fig. 7. Figure 8 shows the comparison of relations $\delta=f\left(F, R_{e}\right)$ obtained for $R=1.3812 \mathrm{~mm}^{-1}$ based on the theoretical (Eq. (7)) and measurement (Eq. (9)) models. Charts for other values of $R=2.5737$ and $3.9182 \mathrm{~mm}^{-1}$ are very similar.

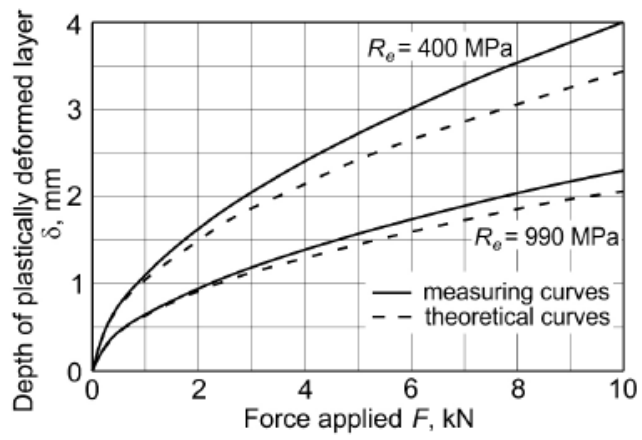

Fig. 7. Effect of the force applied $F$ on the depth of the plastically deformed layer $\delta$ determined for $R=1.3812 \mathrm{~mm}^{-1}$.

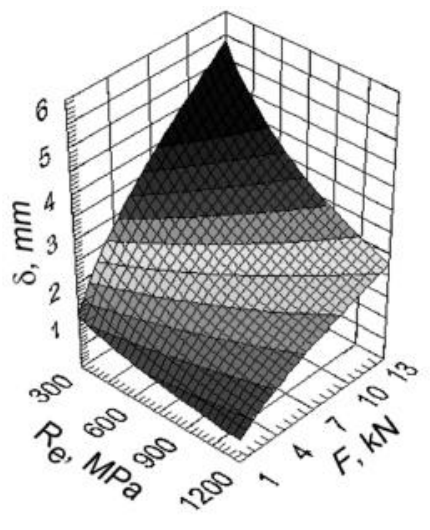

a

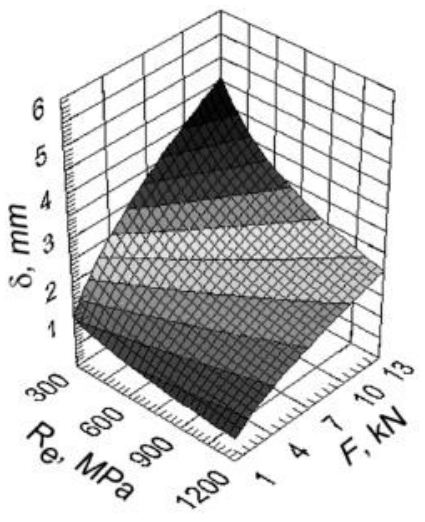

b

Fig. 8. Effect of the force applied $F$ and yield stress $R_{e}$ on the depth of the plastically deformed layer $\delta$ determined for $R=1.3812 \mathrm{~mm}^{-1}$ according to measurements (a) and the theoretical model (b). 
The depth of the plasticized layer after passing the burnishing roller is shown in Fig. 9. The distributions shown in the longitudinal cross-section of the shaft (Fig. 9) correspond to the equivalent plastic strain. For non-proportional loading, the equivalent plastic strain due to cold working is determined using Eq. (10),

$$
d \varepsilon_{p}=\frac{\sqrt{2}}{3} \sqrt{\left(d \varepsilon_{1}^{p}-d \varepsilon_{2}^{p}\right)^{2}+\left(d \varepsilon_{1}^{p}-d \varepsilon_{3}^{p}\right)+\left(d \varepsilon_{3}^{p}-d \varepsilon_{2}^{p}\right)^{2}},
$$

where $d \varepsilon_{p}$ is the equivalent plastic strain increment, and $d \varepsilon_{i}^{p}(i=1,2,3)$ represents the increment in the principal plastic strain components.
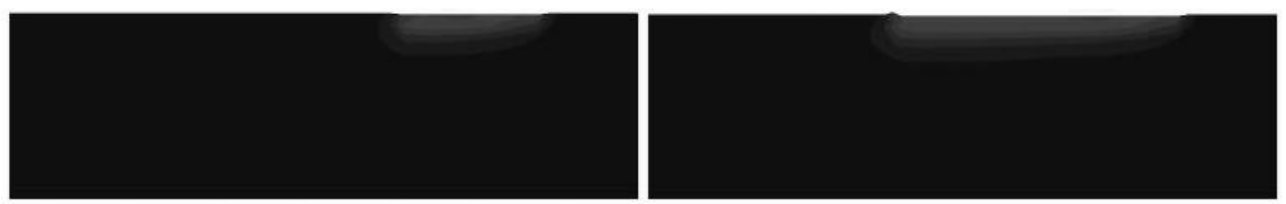

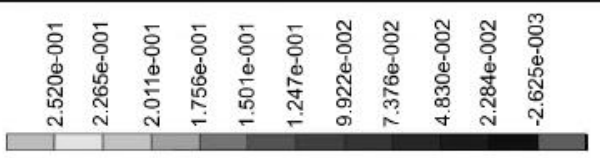

a

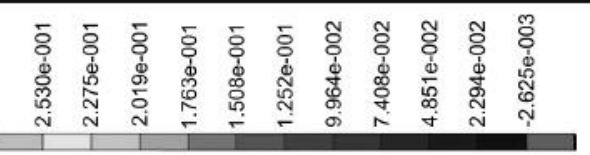

b
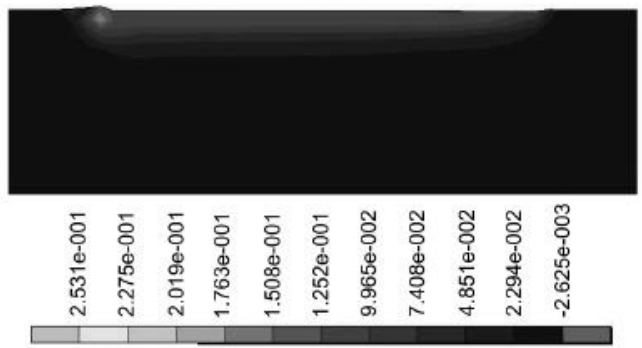

C

Fig. 9. The plastic zone after roller burnishing on a width of shaft of 10 (a), 20 (b) and $30 \mathrm{~mm}$ (c).

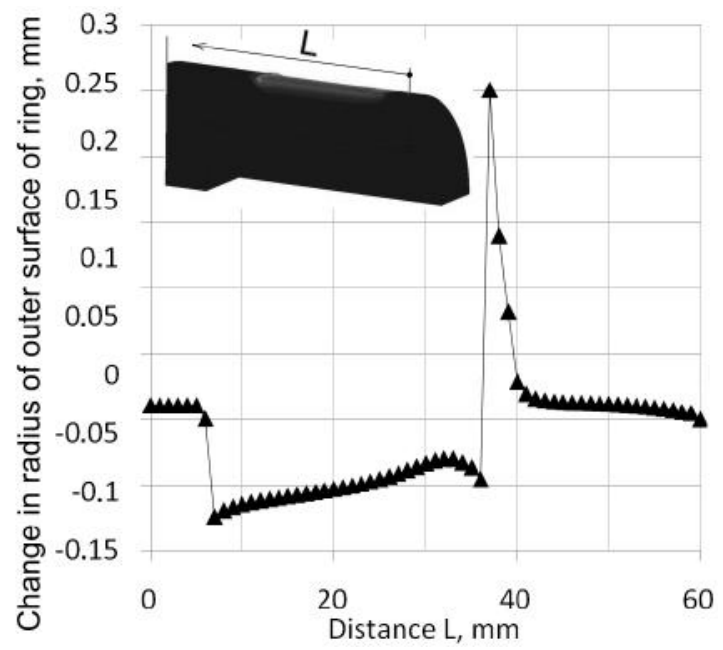

Fig. 10. Change in the radius of the outer surface of the ring after roller burnishing at a distance of $30 \mathrm{~mm}$. 
The formation of the front zone of the deformation is visible, preceding the movement of the roll. The depth of the plastic subsurface deformation of the material in the range of $\varepsilon_{p}=0.074-0.17$ is about $0.78 \mathrm{~mm}$. The range of plastic deformations below the value $\varepsilon_{p}=0.074$ reaches $2.6 \mathrm{~mm}$.

The height of the material bulge preceding the roll movement increases with the increase of the width of the burnished zone, and after passing the roll at a distance of $30 \mathrm{~mm}$ reaches a height of about $0.25 \mathrm{~mm}$ (Fig. 10). The width of the burnished zone also determines the change in the depth of the plastic zone due to the elastic springback of the material. Thus, the change in the radius of the outer surface of the ring is different along the roller displacement. The average decrease in the radius of the outer surface of the roller is about $0.1 \mathrm{~mm}$.

Conclusions. In the process of roller burnishing, it is important to determine the depth of the plastically deformed layer, which is an important factor for increasing fatigue strength. The main technological parameters affecting the depth of deformation of the surface layer are the yield stress of the material $R_{e}$, roller force $F$, and geometry of the roller determined by its diameter $D$ and its radius of curvature $r$. The depth of the plastic deformation can be determined analytically using the Hertz-Bielayev theory for the contact of two elastic bodies assuming symmetry of the process. In this paper, adequate mathematical models were developed to evaluate the depth of the plastically deformed surface layer as a function of force and geometry of the tool. A simple experimental method based on the measurement of the deformation of the face of the rings is consistent with the results of the analytical and numerical calculations.

\section{Резюме}

Представлены методики определения глубины пластично деформированного верхнего слоя материала в процессе обкатывания роликом. Аналитический метод разработан на основе теории Герца-Беляева. Глубина такого слоя получена как функция усилия обкатывания, прочности материала и геометрии ролика. Аналитическое решение проверено оригинальным методом, основанным на измерении лицевого профиля колец. Разработаны математическая модель теоретического решения и план экспериментов. Численное моделирование глубины пластично деформированного слоя выполнено методом конечных элементов. Результаты, полученные аналитическим и экспериментальным методами, показывают их хорошее соответствие.

1. G. Totten, M. Hower, and T. Inove, Handbook of Residual Stress and Deformation of Steel, ASM International, Materials Park, OH (2002).

2. P. Zhang, J. Lindemann, W. J. Ding, and C. Leyens, "Effect of roller burnishing on fatigue properties of the hot-rolled $\mathrm{Mg}-12 \mathrm{Gd}-3 \mathrm{Y}$ magnesium alloy," Mater. Chem. Phys., 124, No. 1, 835-840 (2010).

3. J. Jaworski and T. Trzepieciński, "Research on durability of turning tools made of low-alloy high-speed steels," Kovove Mater., 54, No. 1, 17-25 (2016).

4. W. Napadłek, "The impact of the output stereometry and absorbent coating on the efficiency of ablative laser texturing of iron alloy 100CrMnSi6-4," Mater. Test., 57, No. 10, 920-924 (2015).

5. C. Wang, R. Ma, J. Zhao, and J. Zhao, "Calculation method and experimental study of coulomb friction coefficient in sheet metal forming," J. Manuf. Process., 27, 126-137 (2017).

6. T. Trzepieciński, A. Bazan, and H. G. Lemu, "Frictional characteristics of steel sheets used in automotive industry," Int. J. Automot. Technol., 16, No. 5, 849-863 (2015). 
7. M. Kowalik, M. Rucki, P. Paszta, and R. Gołebski, "Plastic deformations of measured object surface in contact with undeformable surface of measuring tool," Meas. Sci. Rev., 16, No. 5, 1-6 (2016).

8. P. Balland, L. Tabourot, F. Degre, and V. Moreau, "An investigation of the mechanics of roller burnishing through finite element simulation and experiments," Int. J. Mach. Tool. Мanu., 65, 29-36 (2013).

9. M. Okada, S. Suenobu, K. Watanabe, et al., "Development and burnishing characteristics of roller burnishing method with rolling and sliding effects," Mechatronics, 29, 110-118 (2015).

10. M. Kowalik, "Influence of deformation on the structure and properties of materials in longitudinal cold rolling of multidiameter shafts," Mater. Sci., 46, No. 5, 679-684 (2011).

11. B. Zabkar and J. Kopač, "An investigation into roller burnishing," J. Prod. Eng., 16, No. 2, 45-48 (2013).

12. R. J. Kosarevych, B. P. Rusyn, and R. V. Torska, "Modeling of the propagation of pitting corrosion by point processes," Mater. Sci., 51, No. 5, 673-681 (2016).

13. B. P. Rusyn, N. P. Anufrieva, N. R. Hrabov'ska, and V. H. Ivanyuk, "Testing of the state of surfaces damaged by corrosion pitting," Mater. Sci., 49, No. 4, 516-524 (2014).

14. J. Jezierski and T. Mazur, "Analysis of the thickness of the plasticized zone in the surface burnishing process," Arch. Mech. Eng., 49, No. 2, 105-126 (2002).

15. M. Kowalik, "Application of longitudinal cold rolling method in mass production of stepped shafts used in combustion engines," Arch. Civ. Mech. Eng., 10, No. 4, 45-56 (2010).

16. Y. Yanagisawa, Y. Kishi, and K. Sasaki, "Analysis of residual stresses during heat treatment of large forged shafts considering transformation plasticity and creep deformation," Strength Mater., 49, No. 2, 239-249 (2017).

17. D. Skrochocki and J. Tomczak, "Numerical simulation of rotary compression process of hollow balls," Strength Mater., 48, No. 4, 583-591 (2016).

18. B. P. Rusyn, R. V. Torska, and M. I. Kobasyar, "Application of the cellular automata for obtaining pitting images during simulation process of their growth," Adv. Intell. Syst. Comp., 242, 299-306 (2014).

19. V. I. Rizov, "Analysis of longitudinal cracks in multilayered beams with account of the material nonlinearity," Strength Mater., 49, No. 6, 856-864 (2017).

20. L. Malag, L. Kukielka, K. Kukielka, et al., "Problems determining of the mechanical properties of metallic materials from the tensile test in the aspect of numerical calculations of the technological processes," Appl. Mech. Mater., 474, 454-459 (2014).

21. H. Hertz, "Über die Berührung fester elastischer Körper," J. Reine Angew. Math., 92, 156-171 (1881).

22. N. M. Bielayev, Strength of Materials, MON, Warsaw (1954).

23. R. von Mises, "Mechanik der festen Körper im plastisch-deformablen Zustand," Math.-Phys. Klasse, 4, 582-592 (1913).

24. I. M. Gryadunov, S. Y. Radchenko, D. O. Dorokhov, and P. G. Morrev, "Deep hardening of inner cylindrical surface by periodic deep rolling - burnishing process," Modern Appl. Sci., 9, No. 9, 251-258 (2015). 
25. A. Rodriguez, L. N. López de Lacalle, A. Celaya, et al., "Surface improvement of shafts by the deep ball-burnishing technique," Surf. Coat. Tech., 206, Nos. 11-12, 2817-2824 (2012).

26. MSC.Marc 2010. Volume A: Theory and User Information, MSC Software Corporation, Santa Ana, CA (2010).

27. M. Kowalik and T. Trzepieciński, "Numerical and experimental estimation of forces during longitudinal rolling process of shaft formation," Arab. J. Sci. Eng., 39, No. 2, 1259-1260 (2014).

Received 01. 09. 2017 